\title{
FAKTOR-FAKTOR YANG MEMPENGARUHI KEPATUHAN PENYELENGGARA PELAYANAN PUBLIK PEMERINTAH KOTA BATAM
}

\author{
Meri Enita Puspita Sari, Yustinus Farid Setyobudi, Diah Ayu Pratiwi \\ Dosen Tetap Prodi Ilmu Pemerintahan, Universitas Riau Kepulauan Batam
}

\begin{abstract}
\end{abstract}
This research entitled Factors Affecting Compliance Implementation of Public Service Government of Batam. This study aims to determine the factors that influence the level of compliance of public service providers in the City of Batam. This research is useful to provide recommendations solutions and strategies to improve adherence public service providers.This research is a qualitative descriptive study. This study took place at the Department of Health and Department of Education Batam. The variables of this study were (1) Factors compliance behavior as independent variables, (2) Compliance with the Public Service Operator in accordance with Law No. 25 About the Public Service as the dependent variable. Data collection techniques with observation, interviews and documentation and questionnaires as secondary data. This research data analysis techniques using analysis of data reduction, data presentation and conclusion / verification.

Results of this study based on behavioral factors, namely compliance in providing services to the public, the Department of Education and the Health Department in the knowledge, attitudes and actions in providing the services referred to Batam City Government Regional Regulation No. 1 Year 2014 on the Implementation of Public Service. While in service execution factors that in the implementation of the service to the community, the Department of Education and Department of Health have conducted according to the standards of service prescribed by the Government of Batam in accordance with Regulation No. 1 Year 2014 area Implementation of services carried out can be seen that the start of the awareness factor, organizational factors, factors rule, factor income, capabilities and skills, as well as service facilities factor, getting a response different from service users (community). Of the six factors are used as indicators of the implementation of services in this study, the factors factor rules and service facilities are under the spotlight of the public. Based on observations and interviews conducted are still many people who complained about how far the service provider to provide services not in accordance with service standards are displayed in the object of research.

Conclusion The research is Factors compliance behavior: In providing service to the community, required the Department of Education and Department of health knowledge, attitudes and actions in providing the services referred to Batam City Government Regional Regulation No. 1 Year 2014 on the Implementation of Public Service. But the results of this research that the compliance behavior factor still does not work as mandated by the Act. And Factor implementation of the service: In the implementation of service to the community, the Department of Education and Department of Health have conducted according to the standards of service prescribed by the Government of Batam in accordance with Regional Regulation No. 1 Year 2014. Implementation of services carried out can be 
seen that the factors of consciousness, organization, rules, income, ability and skills, as well as service facilities, got a different response from the service users (community). Of the six factors are used as indicators of the implementation of services in this study, the factors factor rules and service facilities are under the spotlight of the public. Based on observations and interviews conducted are still many people who complained about how far the service provider to provide services not in accordance with service standards are displayed in the object of research.

Keywords: compliance, implementing service, local government, public service

\section{Abstrak}

Penelitian ini berjudul Faktor-faktor yang Mempengaruhi Kepatuhan Penyelenggara Pelayanan Publik Pemerintah Kota Batam. Penelitian ini bertujuan untuk mengetahui faktorfaktor apakah yang mempengaruhi tingkat kepatuhan penyelenggara pelayanan publik di pemerintah Kota Batam. Penelitian ini bermanfaat untuk memberikan rekomendasi solusi dan strategi untuk meningkatkan kepatuhan penyelenggara pelayanan publik.

Penelitian ini merupakan penelitian deskriptif kualitatif.Penelitian ini bertempat di Dinas Kesehatan dan Dinas Pendidikan Kota Batam.Variabel penelitian ini adalah (1) Faktor perilaku kepatuhan sebagai independent variable, (2) Kepatuhan Penyelenggara Pelayanan Publik sesuai UU No. 25 Tentang Pelayanan Publik sebagai dependent variable. Tehnik pengumpulan data dengan Observasi, wawancara dan Dokumentasi dan angket sebagai data sekunder.Teknik analisis data penelitian ini menggunakan analisa reduksi data, penyajian data dan penarikan kesimpulan/ verifikasi.

Hasil penelitian ini berdasarkan Faktor perilaku kepatuhan yaitu dalam memberikan layanan terhadap masyarakat, Dinas Pendidikan dan Dinas kesehatan tersebut secara pengetahuan, sikap dan tindakan dalam memberikan layanan mengacu kepada Peraturan Daerah Pemerintah Kota Batam No 1 Tahun 2014 tentang Penyelenggaraan Pelayanan Publik. Sedangkan dalam faktor pelaksanaan pelayanan yaitu Dalam pelaksanaan pelayanan terhadap masyarakat, Dinas Pendidikan dan Dinas kesehatan telah melaksanakan sesuai dengan standar pelayanan yang ditentukan oleh Pemerintah Kota Batam sesuai dengan Perda Pemerintah Kota Batam No 1 Tahun 2014. Penyelenggaraan pelayanan yang dilaksanakan dapat diketahui bahwa mulai dari faktor kesadaran, faktor organisasi, faktor aturan, faktor pendapatan, kemampuan dan keterampilan, serta faktor sarana pelayanan, mendapat respon yang berbeda-beda dari pengguna layanan (masyarakat). Dari keenam faktor pelaksanaan pelayanan yang dijadikan indikator dalam penelitian ini, faktor aturan dan faktor sarana pelayanan yang mendapat sorotan dari masyarakat. Berdasarkan hasil observasi dan 
wawancara yang dilakukan masih banyak masyarakat yang mengeluhkan betapa jauhnya pemberi layanan dalam memberikan layanan yang belum sesuai dengan standar pelayanan yang terpampang di objek penelitian.

Kesimpulan penelitian adalah Faktor perilaku kepatuhan : Dalam memberikan layanan terhadap masyarakat, Dinas Pendidikan dan Dinas kesehatan tersebut secara sikap dan tindakan dalam memberikan layanan mengacu kepada Peraturan Daerah Pemerintah Kota Batam No 1 Tahun 2014 tentang Penyelenggaraan Pelayanan Publik dan Faktor pelaksanaan pelayanan : Dalam pelaksanaan pelayanan terhadap masyarakat, Dinas Pendidikan dan Dinas kesehatan telah melaksanakan sesuai dengan standar pelayanan yang ditentukan oleh Pemerintah Kota Batam sesuai dengan Perda Pemerintah Kota Batam No 1 Tahun 2014. Penyelenggaraan pelayanan yang dilaksanakan dapat diketahui bahwa mulai dari faktor kesadaran, faktor organisasi, faktor aturan, faktor pendapatan, kemampuan dan keterampilan, serta faktor sarana pelayanan, mendapat respon yang berbeda-beda dari pengguna layanan (masyarakat). Dari keenam faktor pelaksanaan pelayanan yang dijadikan indikator dalam penelitian ini, faktor aturan dan faktor sarana pelayanan yang mendapat sorotan dari masyarakat. Berdasarkan hasil observasi dan wawancara yang dilakukan masih banyak masyarakat yang mengeluhkan betapa jauhnya pemberi layanan dalam memberikan layanan yang belum sesuai dengan standar pelayanan yang terpampang di objek penelitian.

\section{Kata Kunci : Kepatuhan, Penyelenggara Pelayanan, Pemerintah Daerah, Pelayanan Publik}

\section{BAB I PENDAHULUAN}

\section{A. Latar Belakang}

Otonomi daerah menjadi salah satu jalan terang yang dapat meningkatkan kualitas pelayanan publik, karena dengan adanya otonomi daerah penyelenggara pelayanan publik dapat memberikan inovasi-inovasi yang berbeda dengan menyesuaikan kondisi daerahnya yang mampu meningkatkan kualitas pelayanan publik antara penyelenggara pelayanan publik dengan penerima pelayanan. Dwiyanto (2006) menyatakan bahwa pelayanan publik menjadi suatu instrument penting untuk dapat mewujudkan good governance. Namun, fakta yang terjadi masih banyak penyelenggaraan pelayanan yang tidak sesuai dengan standard pelayanan dan aturan yang berlaku.

Hasil kajian yang dilakukan Governance and Decentralization Survey 2002 (surajuddin, dkk.2011:4-5), menemukan tiga masalah penting yang perlu disikapi dalam 
menyelenggarakan pelayanan publik pasca diberlakukan peraturan otonomi daerah, yaitu diskriminasi pelayanan, tidak adanya kepastian pelayanan, dan rendahnya tingkat kepuasan masyarakat terhadap pelayanan publik.

Demikian juga hasil kajian yang dilakukan oleh Governance Assesment Survey (GAS) tahun 2006 (surajuddin,dkk.2011 :5) yang menunjukaan bahwa pemerintah belum dapat menyelenggarakan pelayanan dan kebijakan publik dengan baik yang ditunjukkan dengan rendahnya aksesbilitas berbagai jenis pelayanan publik di daerah.

Pelayanan publik adalah kegiatan atau rangkaian kegiatan dalam rangka pemenuhan kebutuhan pelayanan sesuai dengan peraturan perUndang-Undangan bagi setiap warga Negara dan penduduk atas barang, jasa, dan/ atau pelayanan administratif yang disediakan oleh penyelenggara pelayanan publik (UU RI No.25 Tahun 2009 Tentang Pelayanan Publik).

Dalam rangka pemenuhunan kebutuhan pelayanan tersebut dibutuhkan sebuah standar pelayanan yang mampu meberikan akses kemudahan bagi masyarakat dan maklumat pelayanan, sistem informasi pelayanan publik, sarana, prasarana dan/atau fasilitas pelayanan publik, pelayanan khusus, pengelolaan pengaduan dan sistem pelayanan terpadu sesuai dengan Undang-Undang No. 25 Tahun 2009 Tentang Pelayanan Publik.

Kewajiban penyelenggara pelayanan publik dalam menjalankan amanah yang tertuang dalam Undang-Undang Pelayanan Publik belum terealisasi dengan baik di Indonesia, baik di tingkat pusat maupun di tingkat daerah. lemahnya partisipasi masyarakat dalam mengawasi proses pelayanan publik mempeburuk kondisi birokrasi pelayanan publik di Indonesia.

Di Kota Batam, banyak masyarakat yang tidak menyadari bahwa masyarakat berhak untuk memperoleh kejelasan pelayanan, kepastian waktu dan biaya pelayanan, akurasi pelayanan, keamanan pelayanan, pertanggungjawaban pelayanan, kemudahan akses layanan, profesionalitas dan kenyamanan pelayanan sebagaimana prinsip-prinsip pelayanan publik dapat terpenuhi. Lemahnya tingkat pengetahuan terhadap hak dan kewajiban tersebut akan membuat rawan terjadinya KKN yang akan merugikan masyarakat itu sendiri.

Berdasarkan penelitian survey yang dilakukan oleh Ombudsman Perwakilan Kepulauan Riau Tahun 2013 untuk melihat kepatuhan dalam pelaksanaan UndangUndang Nomor 25 Tahun 2009 tentang Pelayanan Publik Sebanyak 76,9\% atau 21 SKPD masuk dalam zona merah yang berarti rendah tingkat kepatuhannya, Sebanyak 19,2\% 
atau 5 SKPD masuk kedalam zona kuning atau zona tengah, yang berarti sedang tingkat kepatuhannya dalam pelaksanaan UU 25 Tahun 2009 tentang Pelayanan Publik, Tidak ada SKPD di Kota Batam yang masuk dalam zona hijau yang berarti tinggi tingkat kepatuhannya dalam pelaksanaan UU 25 Tahun 2009 tentang Pelayanan Publik.

Rendahnya tingkat kepatuhan terhadap penyelenggaraan pelayanan publik di kota Batam akan berdampak terhadap turunnya kulitas pelayanan, rendahnya kepuasan masyarakat, dan akan menurunkan tingkat kepercayaan masyarakat terhadap pemerintah sebagai aparat penyelenggara pelayanan publik.

Banyak penelitian yang telah dilaksanakan sebelumnya tentang peningkatan kualiatas pelayanan publik, implementasi standar pelayanan minimal bahkan kepatuhan terhadap penyelenggaraan pelayanan publik yang telah dilakukan oleh Ombudsman RI, Penelitian-penelitian sebelumnya masih menganalisis tentang proses implementasi dan evaluasinya saja. Namun demikian, penelitian mengenai Faktor-faktor yang mempengaruhi rendahnya kepatuhan penyelenggara pelayanan publik dalam menyelenggarakan pelayanan masih belum begitu banyak. Sehingga perlunya dilaksankan penelitian guna memberikan rekomendasi terhadap aparatur penyelenggara pelayanan publik.

\section{B. Rumusan Masalah}

Berdasarkan latar belakang yang sudah disampaikan sebelumnya, sehingga rumusan masalahnya adalah :

"Apakah faktor-faktor yang mempengaruhi kepatuhan penyelenggara pelayanan publik di Kota Batam ?"

\section{Batasan Penelitian}

Penelitian ini mengambil sampel pada Satuan Kerja Pemerintah Daerah (SKPD) Kota yang menyelenggarakan pelayanan publik Dasar yaitu Dinas Kesehatan dan Dinas Pendidikan Pemerintahan Kota Batam.

\section{Metode Penelitian}

\section{A. Waktu dan Tempat Penelitian}

Pelaksanaan Penelitian ini dari bulan April- November 2015. Penelitian ini bertempat di Dinas Kesehatan dan Dinas Pendidikan Pemerintahan Kota Batam.

\section{B. Jenis Penelitian}

Jenis Penelitian ini adalah penelitian deskriftif dengan menggunakan pendekatan kualitatif. Dengan penelitian ini diharapkan peneliti mengetahui faktor-faktor yang mempengaruhi kepatuhan penyelenggara pelayanan publik dalam menyelenggarakan 
pelayanan publik. Dalam kajian ini akan diketahui hambatan/kendala terhadap lemahnya kepatuhan penyelenggara pelayanan publik dalam memberikan pelayanan sesuai dengan Undang-Undang yang berlaku.

\section{Proses Pengumpulan Data}

Pengumpulan data dilakukan untuk memperoleh informasi yang dibutuhkan dalam rangka mencapai tujuan penelitian. Data dikumpulkan dari sampel yang telah ditentukan sebelumnya. Sampel tersebut terdiri atas sekumpulan unit analisis sebagai sasaran penelitian. Pengumpulan data dalam penelitian ini menggunakan tehnik snowball sampling,tehnik ini digunakan untuk memperoleh informan dalam organisasi atau kelompok yang terbatas untuk menemukan informan yang tepat.

\section{Tehnik Pengumpulan Data}

Tehnik yang digunakan dalam penelitian ini adalah :

a. Observasi atau pengamatan adalah aktivitas pencatatan fenomena yang dilakukan secara sistematis.

b. Wawancara, metode ini digunakan dengan pedoman wawancara.

c. Kuesioner, metode ini dilakukan dengan membuat daftar pertanyaan yang akan diberikan kepada orang lain agar memberikan respon sesuai dengan permintaan.

d. Dukumentasi, metode ini digunakan untuk menelusuri data historis.

\section{E. Teknik Analisis Data}

Penelitian ini menggunakan tehnik analisa yaitu :

i. Data Reduction ( Reduksi Data) yaitu proses pemilihan, pemusatan perhatian pada penyederhanaan, pengabstrakan, dan transformasi data kasar yang muncul dari catatan-catatan tertulis dari lapangan.

ii. Data Display (Penyajian Data) yaitu sekumpulan informasi tersusun yang memberi kemungkinan adanya penarikan kesimpulan dan pengambilan tindakan.

iii. Conclusion Drawing/ verification (Penarikan Kesimpulan / verifikasi yaitu penarikan arti data yang telah ditampilkan.

\section{BAB II TINJAUAN PUSTAKA}

\section{A. Teori Kepatuhan}

Menurut Anonim (2008) tingkat kepatuhan adalah pengukuran pelaksanaan kegiatan, yang sesuai dengan langkah-langkah yang telah ditetapkan, perhitungan tingkat kepatuhan dapat dikontrol bahwa pelaksanaan program telah melaksanakan kegiatan sesuai standar. 
Tingkat kepatuhan menjadi faktor yang mempengaruhi dalam meningkatkan kualitas pelayanan publik. Menurut Sirajuddin, dkk ( 2011:12) menjelaskan pelayanan publik dari persfektif hukum yaitu suatu kewajiban yang diberikan oleh konstitusi atau peraturan perundang-undangan kepada pemerintah untuk memenuhi hak-hak dasar warga Negara atau penduduknya atas suatu pelayanan. Hukum pelayanan publik diartikan sebagai seperangkat norma hukum tentang pemenuhan keinginan dan kebutuhan masyarakat oleh penyelenggara Negara yang dituangkan baik secara tertulis maupun tidak tertulis, yang mengikat pemerintah sebagai pemberi pelayanan publik dan warga negara sebagai penerima layanan publik secara keseluruhan, dan dengan ancaman sanksi bagi pelanggar aturan tersebut.

Dalam penelitian ini, kepatuhan yang dimaksud adalah kepatuhan penyelenggara pelayanan publik dalam menyelenggarakan pelayanan publik sesuai dengan peraturan perundang-undangan yang berlaku yaitu Undang-Undang No.25 tahun 2009 tentang Pelayanan Publik yang mengatur pelayanan publik dari dimensi :

1. Pengertian dan batasan penyelenggaraan pelayanan publik.

2. Asas, tujuan dan ruang lingkup penyelenggaraan pelayanan publik.

3. Pembinaan dan penataan pelayanan publik.

4. Hak, kewajiban dan larangan bagi seluruh pihak yang terkait dalam penyelenggaraan pelayanan publik.

5. Aspek penyelenggaraan pelayanan publik yang meliputi standar pelayanan, maklumat pelayanan, sistem informasi, sarana dan prasaran, biaya/tariff pelayanan, pengelolaan pengaduan, penilaian kinerja.

6. Peran serta masyarakat.

7. Penyelesaian pengaduan dalam penyelenggaraan pelayanan.

8. Sanksi.

Adapun faktor- faktor yang mempengaruhi perilaku kepatuhan menurut Notoatmodjo (2003) adalah :

1. Pengetahuan

Pengetahuan adalah merupakan hasil dari "tahu", dan ini terjadi setelah orang melakukan penginderaan terhadap suatu objek tertentu. Pengukuran pengetahuan dapat dilakukan dengan wawancara yang menanyakan sesuatu yang ingin diukur tentang pengetahuan dari subjek penelitian.

2. Sikap 
Sikap merupakan reaksi atau respon seseorang yang masih tertutup terhadap suatu stimulus atau objek. Sikap terdiri dari 3 komponen (allport (1954) dalam Notoatmodjo (2003)) menjelaskan bahwa sikap terdiri atas 3 komponen pokok, yaitu :

a. Kepercayaan (keyakinan), ide dan konsep terhadap suatu objek.

b. Kehidupan emosional atau evaluasi emosional terhadap suatu objek.

c. Kecendrungan untuk bertindak (trend to behave)

3. Tindakan

Tindakan adalah Realisasi dari pengetahuan dan sikap menjadi suatu perbuatan nyata. Tindakan juga merupakan respon seseorang terhadap stimulus dalam bentuk nyata dan terbuka. Empat tingkatan tindakan:

a. Persepsi (perception)

b. Respon terpimpin (Guide Response)

c. Mekanisme (mechanism)

d. Adaptasi (adaptation)

Menurut Moenir (2010:88-127), dalam pelayanan umum terdapat beberapa faktor-faktor yang berpengaruh dalam pelaksanaan pelayanan adalah :

\section{Faktor Kesadaran}

Kesadaran menunjukkan suatu keadaan pada jiwa seseorang yaitu merupakan titik temu atau equilibrium dari berbagai pertimbangan sehingga diperoleh suatu keyakinan, ketenangan, ketetapan hati dan keseimbangan dalam jiwa yang bersangkutan.

2. Faktor Aturan

Aturan adalah perangkat penting dalam segala tindakan dan perbuatan orang. Dalam organisasi kerja aturan dibuat oleh manajemen sebagai pihak yang berwenang mengatur segala sesuatu yang ada di organisasi kerja tersebut. Pertimbangan pertama manusia sebagai subyek aturan ditujukan kepada hal-hal yang penting, yaitu :

d. Kewenangan.

e. Pengetahuan dan pengalaman.

f. Kemampuan bahasa.

g. Pemahaman oleh pelaksana.

h. Disiplin dalam pelaksanaan.

3. Faktor Organisasi. 
Organisasi pelayanan yang dimaksud adalah mengorganisasi fungsi pelayanan baik dalam bentuk struktur maupun mekanismenya yang akan berperan dalam mutu dan kelancaran pelayanan. Faktor organisasi dapat dilihat dari :
a. Sistem
b. Prosedur
c. Metode

4. Faktor Pendapatan

Pendapatan ialah seluruh penerimaan seseorang sebagai imbalan atas tenaga dan/atau pikiran yang telah dicurahkan untuk orag lain atau badan/organisasi, baik dalam bentuk uang, natura, maupun fasilitas, dalam jangka waktu tertentu. Penentuan kebutuhan hidup minimal dilakukan dengan 2 cara :

a. Kebutuhan Fisik Minimum.

b. Kebutuhan Hidup Minimum (KHM).

5. Faktor Kemampuan-Keterampilan

kemampuan melaksanakan tugas/ pekerjaan dengan menggunakan anggota badan dan peralatan kerja yang tersedia.

6. Faktor Sarana Pelayanan

Sarana pelayanan yang dimaksud ialah jenis peralatan, perlengkapan kerja dan fasilitas lain yang berfungsi sebagai alat utama/pembantu dalam pelaksanaan pekerjaan, dan juga berfungsi sosial dalam rangka kepentingan orang-orang yang sedang berhubungan dengan organisasi kerja itu. Menurut Moenir (2010:88-127), dalam pelayanan umum terdapat beberapa faktor-faktor yang berpengaruh dalam pelaksanaan pelayanan adalah :

\section{B. Pemerintah Daerah}

Undang-Undang Nomor 32 Tahun 2004 tentang Pemerintahan Daerah merupakan salah satu tonggak pendistribusian pelayanan publik kepada pemerintah daerah. Ketentuan ini mengandung arti pemerintahan daerah telah memperoleh pelimpahan wewenang dari pemerintah pusat berkewajiban melaksanakan pelayanan yang selama ini dilakukan sepenuhnya oleh pemerintah pusat. Pelaksanaan pelayanan tersebut tentunya berdasar pada acuan undang-undang sector dan berbagai pedoman teknis pelaksanaan sebagimana telah diatur dalam beberpapa ketentuan dari instansi pemerintah (surajuddin dkk, 2011:20).

Undang-Undang Nomor 32 Tahun 2004 tentang Pemerintahan Daerah menyatakan bahwa Pemerintahan Daerah adalah penyelenggaraan urusan 
pemerintahan oleh pemerintah daerah dan DPRD menurut asas otonomi dan tugas pembantuan dengan prinsip otonomi seluas-luasnya dalam sistem dan prinsip Negara Kesatuan Republik Indonesia sebagaimana dimaksud dalam Undang-Undang Dasar Negara Republik Indonesia Tahun 1945.

Pemerintahan daerah menyelenggarakan urusan pemerintahan yang menjadi kewenangannya, kecuali urusan pemerintahan yang oleh Undang-Undang ini ditentukan menjadi urusan Pemerintah pusat, meliputi : politik luar negeri, pertahanan, keamanan, yustisi, moneter dan fiskal nasional dan agama.

Pemerintahan Daerah meliputi Pemerintahan Daerah Provinsi yang terdiri atas Pemerintah Daerah Provinsi dan DPRD Provinsi dan Pemerintahan Daerah Kabupaten/Kota yang terdiri atas Pemerintah Daerah Kabupaten/Kota dan DPRD Kabupaten/Kota, yang termasuk dalam Pemerintah daerah adalah Gubernur, Bupati, atau Walikota, dan perangkat daerah sebagai unsur penyelenggara pemerintahan daerah. Perangkat daerah sebagai unsur pembantu kepala daerah dalam penyelenggaraan pemerintahan daerah yang terdiri dari sekretariat daerah, sekretariat DPRD, dinas daerah dan lembaga teknis daerah. Sedangkan organisasi perangkat daerah yang melakukan fungsi pelayanan kepada masyarakat adalah Dinas daerah, lembaga teknis daerah, yang terdiri dari badan, kantor dan rumah sakit. Sedangkan, di daerah kabupaten/kota perangkat daerah yang melakukan tugas dan fungsi pelayanan publik sampai dengan kecamatan dan kelurahan.

\section{Pelayanan Publik}

Pelayanan publik adalah kegiatan atau rangkaian kegiatan dalam rangka pemenuhan kebutuhan pelayanan sesuai dengan peraturan perUndang-Undangan bagi setiap warga Negara dan penduduk atas barang, jasa, dan/ atau pelayanan administratif yang disediakan oleh penyelenggara pelayanan publik (UU RI No.25 Tahun 2009 Tentang Pelayanan Publik).

Pelayanan Publik atau pelayanan umum merupakan segala bentuk jasa pelayanan, baik dalam bentuk barang publik maupun jasa publik yang pada prinsipnya menjadi tanggung jawab dan dilaksanakan oleh instansi pemerintah di pusat, di daerah, dan dilingkungan Badan Usaha Milik Negara atau Badan Usaha Milik Daerah, dalam upaya pemenuhan kebutuhan masyarakat maupun dalam rangka pelaksanaan ketentuan peraturan perundang-undangan (Ratminto dan Atik Septi Winarsih, 207:5). 
Dalam hal ini, standar pelayanan publik sudah diatur dalam Undang-Undang RI No.25 Tahun 2009 Tentang pelayanan Publik dan wajib dilaksanakan oleh penyelenggara pelayanan publik dan dalam Pasal 15 dan Bab V Undang-Undang Nomor 25 Tahun 2009 tentang Pelayanan Publik ini Penyelenggara Pelayanan Publik wajib memenuhi 10 unsur mengenai penyelenggaraan pelayanan publik itu sendiri, yang terdiri atas:

1. Standar Pelayanan

Standar pelayanan adalah tolok ukur yang dipergunakan sebagai pedoman penyelenggaraan pelayanan dan acuan penilaian kualitas pelayanan sebagai kewajiban dan janji penyelenggara kepada masyarakat dalam rangka pelayanan yang berkualitas, cepat, mudah, terjangkau, dan terukur.

Komponen standar pelayanan yang dimaksud sekurang-kurangnya meliputi : dasar hukum, persyaratan, sistem mekanisme dan prosedur, jangka waktu penyelesaian, biaya/tarif, produk pelayanan, sarana, prasarana, atau fasilitas, kompetensi pelaksana, pengawasan internal, penanganan pengaduan, saran dan masukan, jumlah pelaksana, jaminan pelayanan yang dilaksanakan sesuai dengan standar pelayanan, jaminan keamanan dan keselamatan pelayanan dalam bentuk komitmen untuk memberikan rasa aman bebas dari bahaya dan resiko keraguraguan, dan evaluasi kinerja pelaksana.

2. Maklumat Pelayanan

Maklumat pelayanan adalah pernyataan tertulis yang berisi keseluruhan rincian kewajiban dan janji yang terdapat dalam standar pelayanan. Maklumat pelayanan wajib dipublikasikan secara jelas dan luas.

3. Sistem Informasi Pelayanan Publik

Sistem informasi pelayanan publik adalah rangkaian kegiatan yang meliputi penyimpanan dan pengelolaan informasi serta mekanisme penyampaian informasi dari penyelenggara pelayanan publik kepada masyarakat dan sebaliknya dalam bentuk lisan, tulisan latin, tulisan dalam huruf braile, bahasa gambar, dan/atau bahasa lokal, serta disajikan secara manual ataupun elektronik. Sistem informasi pelayanan publik berisi semua informasi pelayanan publik yang berasal dari penyelenggara pelayananan publik pada setiap tingkatan dan sekurang-kurangnya memuat informasi yang meliputi : profil penyelenggara, profil pelaksana, standar pelayanan, maklumat pelayanan, pengelolaan pengaduan, dan penilaian kinerja. 
4. Pengelolaan Sarana, Prasarana, dan/atau Fasilitas Pelayanan Publik.

Penyelenggara pelayanan publik wajib mengelola sarana, prasarana, dan fasilitas pelayanan publik secara efektif, efisien, transparan, akuntabel, dan berkesinambungan serta bertanggung jawab terhadap pemeliharaan dan penggantian sarana, prasarana, dan fasilitas pelayanan publik.Penyelenggara pelayanan publik melakukan analisis dan menyusun daftar kebutuhan sarana, prasarana, dan fasilitas pelayanan publik dan melakukan pengadaan sesuai dengan peraturan perundang-undangan dengan mempertimbangkan prinsip efektivitas, efisiensi, transparansi, akuntabilitas, dan berkesinambungan.

5. Pelayanan Khusus

Penyelenggara pelayanan publik berkewajiban memberikan pelayanan dengan perlakuan khusus kepada anggota masyarakat tertentu antara lain penyandang cacat, lanjut usia, wanita hamil, anak-anak, korban bencana alam, dan korban bencana sosial sesuai dengan peraturan perundang-undangan dan diberikan tanpa tambahan biaya.

6. Biaya/Tarif Pelayanan Publik

Biaya/tarif pelayanan publik pada dasarnya merupakan tanggung jawab negara dan/atau masyarakat. Penentuan biaya/tarif pelayanan publik ditetapkan dengan persetujuan Dewan Perwakilan Rakyat, Dewan Perwakilan Rakyat Daerah Provinsi, Dewan Perwakilan Rakyat Daerah Kabupaten/Kota dan berdasarkan peraturan perundang-undangan.

7. Perilaku Pelaksana dalam Pelayanan

Pelaksana pelayanan publik dalam menyelenggarakan pelayanan publik harus berperilaku sesuai paradigma umum yang berlaku di masyarakat yang diantaranya : adil dan tidak diskriminatif, cermat, santun dan ramah, tegas, andal dan tidak memberikan putusan yang berlarut-larut, profesional, tidak mempersulit, patuh pada perintah atasan yang sah dan wajar, menjunjung tinggi nilai-nilai akuntabilitas dan integritas institusi penyelenggara, tidak membocorkan informasi atau dokumen yang wajib dirahasiakan sesuai dengan peraturan perundang-undangan, terbuka dan mengambil langkah yang tepat untuk menghindari benturan kepentingan, tidak menyalahgunakan sarana dan prasarana serta fasilitas pelayanan publik, tidak memberikan informasi yang salah atau menyesatkan dalam menanggapi permintaan informasi serta proaktif dalam memenuhi kepentingan masyarakat, tidak menyalahgunakan informasi, jabatan 
dan kewenangan yang dimiliki, sesuai dengan kepantasan dan tidak menyimpang dari prosedur.

8. Pengawasan Penyelenggaraan Pelayanan

Pengawasan penyelenggaraan pelayanan publik dilakukan oleh pengawas internal dan pengawas eksternal. Pengawasan internal dilakukan oleh atasan langsung pelaksana pelayanan publik dan oleh pengawas fungsional sesuai dengan peraturan perundang-undangan. Pengawasan eksternal penyelenggara pelayanan publik dilakukan oleh masyarakat (berupa laporan/ pengaduan masyarakat), oleh Lembaga Negara Pengawas Pelayanan Publik (Ombudsman RI), dan oleh DPR, DPRD Provinsi dan DPRD Kabupaten/Kota.

9. Pengelolaan Pengaduan

Penyelenggara berkewajiban menyediakan sarana pengaduan dan menugaskan pelaksana yang kompeten dalam pengelolaan pengaduan serta berkewajiban menyusun mekanisme pengelolaan pengaduan dari penerima pelayanan dengan mengedepankan asas penyelesaian yang cepat dan tuntas.

Juga penyelenggara berkewajiban mengelola pengaduan yang berasal dari penerima layanan, rekomendasi Ombudsman RI, DPR, DPRD Provinsi dan DPRD Kabupaten/Kota dalam batas waktu tertentu, serta berkewajiban menindaklanjuti hasil pengelolaan pengaduan tersebut.

Penyelenggara pelayanan publik juga berkewajiban mengumumkan nama dan alamat penanggung jawab pengelola pengaduan serta sarana pengaduan yang disediakan.

10. Penilaian Kinerja

Penyelenggara pelayanan publik berkewajiban melakukan penilaian kinerja penyelenggaraan pelayanan publik secara berkala dengan menggunakan indikator kinerja berdasarkan standar pelayanan.

\section{Definisi Konseptual}

1. Tingkat kepatuhan adalah pengukuran pelaksanaan kegiatan, yang sesuai dengan langkah-langkah yang telah ditetapkan, perhitungan tingkat kepatuhan dapat dikontrol bahwa pelaksanaan program telah melaksanakan kegiatan sesuai standar. Kepatuhan yang dimaksud adalah kepatuhan penyelenggara pelayanan publik dalam menyelenggarakan pelayanan publik sesuai dengan peraturan 
perundang-undangan yang berlaku yaitu Undang-Undang No.25 tahun 2009 tentang Pelayanan Publik.

2. Pemerintahan Daerah menyatakan bahwa Pemerintahan Daerah adalah penyelenggaraan urusan pemerintahan oleh pemerintah daerah dan DPRD menurut asas otonomi dan tugas pembantuan dengan prinsip otonomi seluasluasnya dalam sistem dan prinsip Negara Kesatuan Republik Indonesia sebagaimana dimaksud dalam Undang-Undang Dasar Negara Republik Indonesia Tahun 1945 ( UU No.32 Tahun 2004 Tentang Pemerintahan Daerah).

3. Pelayanan publik adalah kegiatan atau rangkaian kegiatan dalam rangka pemenuhan kebutuhan pelayanan sesuai dengan peraturan perUndang-Undangan bagi setiap warga Negara dan penduduk atas barang, jasa, dan/ atau pelayanan administratif yang disediakan oleh penyelenggara pelayanan publik (UU RI No.25 Tahun 2009 Tentang Pelayanan Publik).

Berdasarkan tinjauan teoritis dan definisi Konseptual, terdapat faktor-faktor yang mempengaruhi kepatuhan penyelenggara pelayanan publik dalam menyelenggarakan pelayanan publik. Sehingga kerangka berpikirnnya adalah :

\section{Independent Variable}

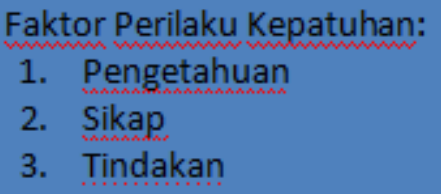




\section{Kepatuhan Penyelenggara Pelayananan \\ Sesuai UU No.25 Tahun 2009 Tentang \\ Pelayanan Publik}

Faktor pelaksanaan pelayanan :

1. Faktor Kesadaran

2. Faktor Organisasi

3. Faktor Aturan

4. Faktor Pendapatan

5. Kemampuanketerampilan

6. Faktor Sarana pelayanan

\section{BAB III PEMBAHASAN}

\section{A. Faktor Perilaku Kepatuhan}

\section{Pengetahuan}

Pengetahuan merupakan hal yang mendasar dalam pemahaman seseorang terhadap kejadian/peristiwa yang dihadapi. Dengan luasnya pengetahuan, sesorang mampu melakukan evaluasi maupun berinovasi dalam melakukan kegiatan.

Dalam penelitian mengenai faktor-faktor yang mempengaruhi kepatuhan penyelenggara pelayanan publik ini, didapat data bahwa belum semua Pemerintah Daerah memahami tentang amanat dari Undang-Undang No 25 tahun 2009 Tentang Pelayanan Publik. Hal ini seperti yang diungkapkan oleh seorang responden di Dinas Pendidikan, sebagai berikut :

"dalam memberikan pelayanan, kami hanya mengacu pada SOP yang kami miliki, kami belum mengetahui bahwa ada UU pelayanan publik. Setahu saya, hanya perda Kota Batam ada yang mengatur tentang pelayanan publik. Tapi perda no berapa, saya pun lupa."

Pernyataan tersebut, sungguh mengherankan bahkan sangat memberi tamparan kepada kita, bahwa ternyata Undang-Undang yang sudah berlaku selama hampir 4 tahun, tapi 
masih belum tersosialisasi sampai pada pegawai negeri sipil yang berada di daerah. Dengan pernyataan tersebut, kami mencoba untuk mencari responden lagi namun di tingkat Kabid, dan hasil yang didapat sebagai berikut :

“dalam UU pelayanan publik, memang sudah diatur mengenai hak dan kewajiban yang harus dilakukan oleh penyelenggara pelayanan public. Namun, dinas kami bukan instansi yang memberikan pelayanan langsung kepada masyarakat. Berbeda dengan RSUD dan Badan Penanaman Modal di Batam Center."

Hasil wawancara tersebut juga membuat peneliti heran, sebagai instansi pemerintah yang merupakan institusi yang menjalankan misi Negara masih beranggapan bahwa yang memberi pelayanan publik itu hanya institusi yang memberikan pelayanan kepada masyarakat secara langsung, seperti kelurahan, kecamatan, RSUD, Badan Penanaman Modal, maupun Disdukcapil.

Padahal dalam UU pelayanan public telah dijelaskan secara detail mengenai pemberi dan penerima layanan. Dalam UU No 25 Tahun 2009 pada Pasal 1 berbunyi sebagai berikut :

1) Pelayanan publik adalah kegiatan atau rangkaian kegiatan dalam rangka pemenuhan kebutuhan pelayanan sesuai dengan peraturan perundang-undangan bagi setiap warga negara dan penduduk atas barang, jasa, dan/atau pelayanan administratif yang disediakan oleh penyelenggara pelayanan publik.

2) Penyelenggara pelayanan publik yang selanjutnya disebut Penyelenggara adalah setiap institusi penyelenggara negara, korporasi, lembaga independen yang dibentuk berdasarkan undang-undang untuk kegiatan pelayanan publik, dan badan hukum lain yang dibentuk semata-mata untuk kegiatan pelayanan publik.

3) Atasan satuan kerja Penyelenggara adalah pimpinan satuan kerja yang membawahi secara langsung satu atau lebih satuan kerja yang melaksanakan pelayanan publik.

4) Organisasi penyelenggara pelayanan publik yang selanjutnya disebut Organisasi Penyelenggara adalah satuan kerja penyelenggara pelayanan publik yang berada di lingkungan institusi penyelenggara negara, korporasi, lembaga independen yang dibentuk berdasarkan undang-undang untuk kegiatan pelayanan publik, dan badan hukum lain yang dibentuk semata-mata untuk kegiatan pelayanan publik.

5) Pelaksana pelayanan publik yang selanjutnya disebut Pelaksana adalah pejabat, pegawai, petugas, dan setiap orang yang bekerja di dalam Organisasi Penyelenggara yang bertugas melaksanakan tindakan atau serangkaian tindakan pelayanan publik.

Terlihat bahwa bunyi pasal 1 mulai ayat 1 sampai ayat 5 menunjukkan bahwa setiap SKPD merupakan satu kesatuan dalam Pemerintah Daerah yang dibentuk oleh undang- 
undang. Walaupun secara tupoksi tidak menjelaskan mengenai pelayanan langsung kepada masyarakat, namun Dinas Pendidikan juga merupakan bagian Pemerintah Daerah yang menjadi penyelenggara pelayanan public yang diamanatkan UU No 25 Tahun 2009.

Berbeda halnya dengan hasil yang diperoleh peneliti di Dinas Pendidikan dengan RSUD Embung Fatimah, bahwa pengetahuan mengenai UU No 25 Tahun 2009 sudah bagus. Namun, dalam pelaksanaan kinerja pegawai RSUD masih berpatokan pada standar pelayanan minimal (SPM) yang dimiliki RSUD tersebut.

Dengan hasil yang didapat oleh peneliti mengenai 6 tingkatan pengetahuan menurut Notoatmojo (2003) belum berjalan maksimal. Karena ternyata pengetahuan dari Dinas Pendidikan Kota Batam dan RSUD Embung Fatimah masih pada tahap aplikasi saja. Hal ini bisa dilihat dengan hasil wawancara tersebut diatas yang menyatakan bahwa pengetahuan mengenai UU pelayanan public masih minim dan hanya sebatas melaksanakan standar operasional prosedur (SOP) dan standar pelayanan minimal (SPM) yang dimilikinya. Secara teori Notoatmojo, 6 tingkatan tersebut sebagai berikut :

a. Tahu (know);

b. Memahami (comprehension);

c. Aplikasi (application);

d. Analisis (analysis);

e. Sintesis (synthesis); dan

f. Evaluasi (evaluation).

Seharusnya pengetahuan yang ada di kedua objek penelitian ini ditambah melalui diklat maupun pelatihan tentang pelayanan public. Padahal PP No 96 Tahun 2012, dan Permenpan No 15 Tahun 2014, serta Permenpan No 16 Tahun 2014 merupakan dasar hukum yang dijadikan juklak dan juknis dalam pelaksanaan UU No 25 tahun 2009 ini.

\section{Sikap}

Sikap merupakan reaksi atau respon seseorang yang masih tertutup terhadap suatu stimulus atau objek, dalam penelitian ini sumber daya manusia yang memang ditugaskan di instansi pelayanan publik untuk memberikan pelayanan yang memuaskan kepada masyarakat dituntut agar memiliki tingkat kepatuhan yang tinggi terhadap peraturan terutama terhadap Undang-undang No.25 Tahun 2009 tentang pelayanan publik, namun tidak dipungkiri bahwa inovasi dan kreativitas dalam memberikan pelayanan juga sangat dibutuhkan untuk meningkatkan kepuasan masyarakat tersebut. Dinas Pendidikan dan Dinas Kesehatan (RSUD Embung Fatimah) pada sejatinya sudah berusaha untuk melaksanakan peraturan yang sudah diamanatkan dalam UU, tapi hal tersebut baru diterapkan dalam bentuk aturan tampak 
fisik (Eligble) yang terkait dengan pelayanan contohnya pemasangan maklumat pelayanan, Standar Pelayanan Minimal (SPM), SOP, Motto dan papan pengumuman. Namun, banyak terjadi ketidakpuasan masyarakat terhadap pelayanan yang diberikan dari segi sikap, karena banyak masyarakat yang kurang mengerti dengan pemaparan standar pelayanan sehingga membutuhkan penjelasan lebih lanjut dari petugas. Petugas yang diberi wewenang untuk menjelaskan tentang pelayanan banyak yang belum mengerti dengan kebijakan yang mereka buat sehingga sering terjadi kesalahpahaman dalam memberi pelayanan.

\section{Tindakan}

Tindakan merupakan realisasi dari pengetahuan dan sikap menjadi suatu perbuatan nyata. Tindakan juga merupakan respon seseorang terhadap stimulus dalam bentuk nyata dan terbuka. Dalam melaksanakan UU no 25 tahun 2009, Dinas pendidikan dan Dinas kesehatan dalam hal ini pengambilan data dilakukan di Rumah sakit embung fatimah sudah melaksanakan beberapa aturan yang tertuang dalam UU namun dari segi pelayanan secara langsung belum maksimal.

\section{B. Faktor Pelaksanaan Pelayanan}

\section{Kesadaran}

Dinas Pendidikan dan Dinas Kesehatan (RS Embung Fatimah) dalam memberikan pelayanan masih belum maksimal, kebanyakan sumber daya manusia yang bertugas terutama di garda depan pelayanan belum memahami arti dari sebuah pelayanan itu sendiri, belum mampu memberikan yang terbaik kepada masyarakat, bahkan ada beberapa petugas yang belum mengerti dengan kebijakan yang dikeluarkan oleh ruma sakit tersebut.

\section{Organisasi}

Seragam dan Kartu identitas atau ID memiliki fungsi tidak hanya sebagai pelengkap atribut pegawai saja, akan tetapi memberi arti tersendiri dalam mendukung formalitas dan image Unit Layanan Publik tersebut. Fungsi dari penggunaan seragam dan ID Card, antara lain :

a) Memberikan kesan positif pada suasana kerja.

b) Memberikan kesan formal dan rapi.

c) Memudahkan pengguna layanan untuk mengenali pegawai.

d) Memisahkan secara tegas antara pegawai dan non pegawai untuk menjaga keamanan, penyusupan, dan hal-hal yang tidak diinginkan.

e) Dengan penggunaan seragam dan kartu id maka sangat memungkinkan untuk penerapan akses kontrol pegawai. 
Berdasarkan hasil penelitian ini didapatkan bahwa Penggunaan ID card pada petugas layanan di Dinas Pendidikan dan Dinas kesehatn mayoritas menggunakan ID card PNS, sedangkan penggunaan seragam hampir mayoritas menggunakan seragam PNS.

\section{Aturan}

Aturan yang dimaksud dalam penelitian ini tertuang dalam Maklumat Layanan (UU No.25 Tahun 2009), Maklumat pelayanan adalah pernyataan tertulis dari Penyelenggara yang berisi janji-janji penyelenggara untuk menjamin bahwa pelayanan yang diberikan sesuai dengan standar pelayanan serta dipublikasikan secara luas sehingga ada komitmen tertulis dan dipajang untuk kemudian dipatuhi oleh penyelenggara layanan tersebut, hal ini menjadi perhatian khusus karena sebanyak $89,7 \%$ dari total sampel tidak memajang maklumat di tempat penyelenggara pelayanan tersebut, tidak ada komitmen yang bisa ditagih oleh pengguna layanan kepada penyelenggara pelayanan. Dari kedua Objek Penelitian yang memajang maklumat pelayanan hanya Rumah Sakit Embung fatimah saja.

Dalam UU No. 25 Tahun 2009 tentang Pelayanan Publik, maklumat menjadi sangat penting untuk ada di setiap penyelenggara pelayanan publik. Sesuai dengan pasal 18 UU No. 25 tahun 2009 disebutkan bahwa Penyelenggara wajib menyusun maklumat pelayanan sesuai dengan sifat, jenis, dan karakteristik layanan yang diselenggarakan dan dipublikasikan secara jelas, selain itu diamanatkan pula pada Pasal 46 bahwa Penyusunan dan pelaksanaan maklumat pelayanan harus dipenuhi selambat-lambatnya 2 (dua) tahun sejak UU ini berlaku.

Manfaat Maklumat Pelayanan jika dapat dilaksanakan secara konsekuen antara lain :

1. Meningkatkan responsivitas petugas pelayanan terhadap stakeholder yg dilayani.

2. Meningkatkan kepuasan masyarakat/pengguna jasa layanan.

3. Meningkatkan kinerja dan kualitas layanan secara menyeluruh.

4. Sebagai dasar Etika bagi service provider.

Selain itu, Maklumat Pelayanan juga berfungsi sebagai :

1. Sebagai infrastruktur/software penyelenggaraan pelayanan.

2. Mendekatkan pejabat publik dengan konstituen melalui ikatan kepatutan.

3. Membangun kredibilitas penyelenggara dan penyelenggaraan pemerintahan melalui pemeliharaan otentisitas. 
4. Mewujudkan idealita tentang pemerintah yang berfokus pada warga negara (citizen centric government).

Oleh karena itu, Unit Layanan Publik di Pemerintah Kota wajib menyusun Maklumat Pelayanan selain sebagai bentuk perjanjian sosial antara penyelenggara layanan publik dengan pengguna layanan public.

\section{Pendapatan}

Pendapatan ialah seluruh penerimaan seseorang sebagai imlan atas tenaga dan/atau pikiran yang telah dicurahkan untuk orang lain atau badan/organisasi, baik dalam bentuk uang maupun fasilitas dalam jangka waktu tertentu. Dalam hal pendapatan pegawai sudah diatur oleh pemerintah dan disesuaikan dengan golonganan dan kepangkatan masing-masing pegawai karena pegawai di Dinas Pendidikan dan Dinas Kesehatan merupakan Pegawai Negeri Sipil.

\section{Kemampuan-ketrampilan}

Penilaian kinerja terhadap pegawai ataupun penyelenggara layanan publik amatlah penting, karena dengan adanya penilaian kinerja dari masyarakat mampu menjadi input bagi penyelenggara layanan publik.

Dari hasil penelitian, Dinas pendidikan dan Dinas Kesehatan Pemerintah Kota Batam belum ada sarana untuk mengukur kepuasaan masyarakat terhadap layanan yang diberikan. Sehingga Masyarakat sangat mengharapkan Dinas pendidikan dan Dinas Kesehatan segera membuat sarana untuk mengukur kepuasaan sebagai bagian dari penilaian kinerja.

\section{Sarana Pelayanan}

Sarana pelayanan merupakan salah satu faktor yang dijadikan peneliti untuk melihat kepatuhan Pemerintah Daerah terhadap Undang-Undang No 25 Tahun 2009. Dalam penelitian ini, yang dijadikan indicator untuk melihat sarana pelayanan yaitu sebagai berikut :

a. Standar Pelayanan

Standar pelayanan dalam layanan publik, dilihat dari beberapa indikator antara lain dasar hukum, persyaratan layanan, SOP, biaya dan jangka waktu layanan, ruang tunggu, tata tertib petugas, serta kode etik petugas. Dan standar pelayanan ini harus dipampang/dipajang di ruangan layanan, sehingga memudahkan pengguna layanan untuk mendapat informasi.

Namun, dalam observasi yang dilakukan oleh tim, Dinas Pendidikan dan Dinas kesehatan sudah memajang informasi untuk persyaratan pelayanan, SOP yang 
merupakan panduan yang sangat penting bagi masyarakat supaya mempermudah untuk mendapat informasi terkait dengan prosedur dalam mengurus perijinan. Walaupun sarana pelayanan di Dinas Pendidikan dan Dinas Kesehatan yang ada di Kota Batam hampir semuanya menyediakan, namun ini berbeda dengan kode etik dan tata tertib petugas yang dipampang/ dipajang. Padahal dengan dipampang/dipajangnya kode etik maupun tata tertib tersebut masyarakat mengetahui bagaimana sikap petugas dalam memberikan layanan, sehingga meminimalisir terjadi maladministrasi.

b. Sistem Informasi Pelayanan Publik

Sistem informasi pelayanan publik adalah rangkaian kegiatan yang meliputi penyimpanan dan pengelolaan informasi serta mekanisme penyampaian informasi dari penyelenggara pelayanan publik kepada masyarakat dan sebaliknya dalam bentuk lisan, tulisan latin, tulisan dalam huruf braile, bahasa gambar, dan/atau bahasa lokal, serta disajikan secara manual ataupun elektronik. Sistem informasi pelayanan publik berisi semua informasi pelayanan publik yang berasal dari penyelenggara pelayananan publik pada setiap tingkatan dan sekurang-kurangnya memuat informasi yang meliputi : profil penyelenggara, profil pelaksana, standar pelayanan, maklumat pelayanan, pengelolaan pengaduan, dan penilaian kinerja.

Sistem informasi pelayanan publik ini adalah media sosialiasi kepada khalayak umum bahwa ada kegiatan pelayanan publik di tempat penyelenggara pelayanan publik tersebut, dalam penelitian ini karena bentuknya adalah pilihan (cetak maupun elektronik) Dinas pendidikan dan Dinas Kesehatan belum memajang/mempublikasikan sistem informasi pelayanan publik ini. Hanya Dispenda yang sudah memajang/memampang system informasi terkait dengan profil penyelenggara, profil pelaksana, maupun standar pelayanan.

c. Pelayanan Khusus

Sebagai catatan, Pasal 29 Undang-Undang Nomor 25 tahun 2009 tentang Pelayanan Publik menyebutkan penyelenggara pelayanan publik wajib memberi pelayanan dengan perlakukan khusus kepada anggota masyarakat tertentu. Masyarakat tertentu adalah kelompok rentan meliputi penyandang cacat, lanjut usia, wanita hamil, anak-anak, korban bencana alam, dan korban bencana sosial. Bukan itu saja, fasilitas dan perlakuan khusus kepada kelompok rentan harus diberikan tanpa pungutan biaya alias gratis. 
Hasil penelitian ini mendapatkan bahwa Dinas pendidikan dan Dinas Kesehatan Kota Batam yang menjadi sampel dalam penelitian ini tidak menyediakan sarana khusus bagi pengguna layanan berkebutuhan khusus tersebut.

Hasil penelitian di atas menjadi bukti empiris yang menunjukkan bahwa masih dijumpainya keadaan yang belum sesuai dengan kondisi yang diharapkan bagi kelompok rentan.

Meskipun sudah diamanatkan oleh Undang-Undang Nomor 25 Tahun 2009, namun demikian fasilitas pelayanan publik bagi kelompok rentan masih sangat minim dan dalam pelaksanaannya pun belum banyak terlihat aksesabilitas pelayanan bagi kelompok rentan terutama bagi penyandang cacat dan para lansia (lanjut usia).

Untuk itu perlu dilakukan reformasi dalam pelayanan publik untuk mewujudkan aparat dan pelayanan publik yang baik dan siap untuk melayani kelompok rentan yang harus dibangun adalah dengan melakukan perubahan mind-set dan culture-set serta pengembangan budaya kerja bagi aparat yang memberikan pelayanan publik, sehingga muncul kesadaran yang tinggi dari aparatur untuk memberikan pelayanan yang sebaik-baiknya bagi masyarakat dan tidak membeda-bedakan masyarakat.

\section{d. Pengelolaan Pengaduan}

Pengaduan masyarakat merupakan bukti adanya penyimpangan atau ketidakpuasan masyarakat/ pengguna layanan dalam penyelenggaraan pelayanan publik, tetapi pengaduan masyarakat juga menjadi sebuah tantangan tersediri bagi penyelenggara layanan untuk bisa memperbaiki dan memberikan layanan yang sesuai dengan yang diharapkan oleh masyarakat. Untuk itu, penyelenggara layanan publik wajib memiliki unit pengaduan khusus untuk dapat menjembatani keluhan yang dirasakan oleh masyarakat demi terwujudnya kualitas dan kepuasan dari masyarakat selaku pengguna layanan.

Sesuai dengan UU No. 25 Tahun 2009, penyelenggara pelayanan berkewajiban menyediakan sarana pengaduan dan menugaskan pelaksana yang kompeten dalam pengelolaan pengaduan serta berkewajiban menyusun mekanisme pengelolaan pengaduan dari penerima pelayanan dengan mengedepankan asas penyelesaian yang cepat dan tuntas.

Hasil penelitian menunjukan Dinas Pendidikan dan Dinas Kesehatan Kota Batam belum menyediakan saluran langsung khusus untuk menerima keluhan masyarakat pengguna pelayanan terhadap kinerja pelayanan publik yang berada dalam wilayahnya, Apapun bentuk saluran yang digunakan untuk memperoleh saran 
atau pengaduan dari masyarakat pengguna pelayanan, tidak akan banyak berarti dan tidak efektif jika saran atau pengaduan yang masuk tidak pernah diolah, ditindaklanjuti dalam bentuk perbaikan nyata dan dikomunikasikan secara efektif kepada para pemberi saran atau para pengadu yang telah menyampaikan keluhan, hal ini bisa dilihat dari hasil penelitian ini dimana Dinas Pendidikan dan Dinas Kesehatan tidak bisa menunjukan informasi laporan hasil pengelolaan pengaduannya selama ini.

Untuk itu, perlu meningkatkan kesadaran kepada pengelola pengaduan pada Unit Layanan Publik tersebut agar ada transparansi dalam pengelolaan pengaduan serta menilai bahwa pengaduan atau keluhan dari masyarakat/penerima layanan memiliki nilai positif, dimana dengan mengetahui kelemahan layanan yang diberikan maka instansi yang bersangkutan akan terdorong untuk memperbaiki kualitas layanannya.

\section{BAB IV KESIMPULAN DAN SARAN}

\section{A. KESIMPULAN}

1. Faktor perilaku kepatuhan :

Dalam memberikan layanan terhadap masyarakat, Dinas Pendidikan dan Dinas kesehatan tersebut secara sikap dan tindakan dalam memberikan layanan mengacu kepada Peraturan Daerah Pemerintah Kota Batam No 1 Tahun 2014 tentang Penyelenggaraan Pelayanan Publik.

2. Faktor pelaksanaan pelayanan :

Dalam pelaksanaan pelayanan terhadap masyarakat, Dinas Pendidikan dan Dinas kesehatan telah melaksanakan sesuai dengan standar pelayanan yang ditentukan oleh Pemerintah Kota Batam sesuai dengan Perda Pemerintah Kota Batam No 1 Tahun 2014. Penyelenggaraan pelayanan yang dilaksanakan dapat diketahui bahwa mulai dari faktor kesadaran, faktor organisasi, faktor aturan, faktor pendapatan, kemampuan dan keterampilan, serta faktor sarana pelayanan, mendapat respon yang berbeda-beda dari pengguna layanan (masyarakat). Dari keenam faktor pelaksanaan pelayanan yang dijadikan indikator dalam penelitian ini, faktor aturan dan faktor sarana pelayanan yang mendapat sorotan dari masyarakat. Berdasarkan hasil observasi dan wawancara yang dilakukan masih banyak masyarakat yang mengeluhkan betapa jauhnya pemberi layanan dalam memberikan layanan yang belum sesuai dengan standar pelayanan yang terpampang di objek penelitian. 


\section{B. SARAN}

Organisasi Pelayanan publik sudah diamanatkan dalam UU untuk memberikan pelayanan publik secara maksimal kepada masyarakat hendaknya mengikuti aturan yang berlaku sehingga masyarakat dapat memiliki rasa nyaman dan kepuasan terhadap birokrasi yang memberikan pelayanan demi mewujudkan good governance.

\section{DAFTAR PUSTAKA}

Bungin, Burhan M. 2008. Penelitian Kualitatif. Kencana. Jakarta.

Hardiyansyah. 2011. Kualitas Pelayanan Publik. Gava Media. Yogyakarta.

Idrus, Muhammad. 2009. Metode Penelitian Sosial. Erlangga. Jakarta.

Moenier. 2010. Manajemen Pelayanan Umum Indonesia. Bumi Aksara. Jakarta.

Notoatmodjo, Soekidjo. 2003. Pendidikan Dan Perilaku Kesehatan. Rineka Cipta. Jakarta

Ombudsman RI Perwakilan Kepulauan Riau. 2013. Laporan Penelitian Kepatuhan Daerah.

Ratminto \& Atik Septi Winarsih. 2006. Manajemen Pelayanan. Penerbit : Pustaka Pelajar. Yogyakarta.

Sirajuddin, dkk. 2011. Hukum Pelayanan Publik. Setara Press.Malang.

Sugiyono. 2012. Metode penelitian Kuantitatif, Kualitatif, dan R\&D. Penerbit : Alfabeta. Bandung.

Undang-Undang Nomor 32 Tahun 2004 tentang Pemerintahan Daerah.

Undang-Undang Republik Indonesia. No. 25 Tahun 2009 Tentang Pelayanan Publik.

Utomo, Warsito. 2009. Reformasi Birokrasi, Kepemimpinan dan Pelayanan Publik. Penerbit : Gava Media. Yogyakarta. 